\title{
Documents and the bureaucratisation of alternative dispute resolution in the United States
}

\author{
Amanda J. Reinke
}

\begin{abstract}
Documents are part of interactive sociocultural worlds in which ethnographers can analyse topics such as power relations, social struggle, violence and secrecy. While they emerge from bureaucratic administration, apparently mundane and stagnant documents represent dynamic processes of decision-making, knowledge production and exclusion. I consider ethnographic research on documents and their production as one that offers significant insights into bureaucratic violence and the tensions between formality and informality in alternative dispute resolution in Virginia and the San Francisco Bay Area. This article discusses working with documents that are simultaneously bound by law and exist extra-legally. While documents are used to gain economic support, strengthen relationships between non-profit and government bodies, and evidence 'success', the processes have difficulties. The data demonstrate that bureaucratisation has resulted in cumbersome processes and expensive requirements that mirror the exclusion and power asymmetries of formal law itself.
\end{abstract}

Keywords: alternative justice, bureaucracy, bureaucratic violence, documents, informal law, United States

Sitting at a small desk under fluorescent lights in an office with no windows, I find myself surrounded by filing cabinets. Tall and wide, each one is filled with case files, and each file is filled with various papers. These cabinets line the walls - a visible marker of our role as bureaucrats - and fill the closet to such an extent that it is difficult to roll the doors closed and hide our documentary clutter. Files are sometimes missing. Information is often incomplete. Cases are marked 'successfully closed' on the file cover even when no agreement was reached. The computer system also provides a digital record of cases; this information occasionally overlaps with that in the hard copy of the file (when both can be located), but also with distinct and separate information. The result is a massive amount of archival information that remains relatively poorly curated. I find it challenging to find 'that document' I need at any given time; searching through paper and digital files is a daily ritual. 
As a new volunteer at a community mediation centre in the San Francisco Bay Area, I was struck by the vast amount of time expended on creating digital and physical paperwork. This kind of alternative dispute resolution (ADR) gained traction in the United States in response to civil rights and feminist movements as means of providing low-cost, accessible and community-driven forms of justice to underserved populations, while simultaneously relieving court dockets (Brown et al. 1997; Reinke 2016). Described by a practitioner and interviewee in Virginia as processes that the state is 'thrilled' with because 'it takes it off their docket and ... I think they really believe in it', ADR was initially envisioned as more expedient, less cumbersome and technical for clients and service providers, and more meaningful in fulfilling the sense of justice. However, it became clear during my research that the bureaucratic machinery required to run such organisations also raised questions about the framework's utility to meet these initial goals.

The goal of offering less harmful conflict resolution mechanisms based in values of empathy, healing, accountability and service was set by alternative justice practitioners in order to achieve broader social justice interests in the United States, such as curbing the school-toprison pipeline, providing financially accessible conflict resolution and subverting mass incarceration. Since its initial popularisation, informal justice has flourished, and while some practitioners work extra-legally, many work with and within the formal legal system, seeking inroads into a justice system they deem violent and antithetical to their definitions of 'justice'.

ADR is a generative space for considering the role of documents in conflict resolution and social justice efforts to mitigate state violence. The absence and presence of documents is leveraged by practitioners working to mitigate the school-to-prison pipeline, subvert mass incarceration and build peace in communities. Meanwhile, complex filing systems, memoranda of understanding with the state, background checks and bureaucratic infrastructures to manage identifications and access to particular places and peoples exist as impediments to achieving social justice goals. While ADR practitioners call for increased bureaucratisation to standardise their work and achieve legitimacy in the eyes of the state, they must simultaneously give up the inherent flexibility and needs-based approach of their framework. This article marshals interviews and observations in the United States to illustrate the ways in which the presence and absence of documents, files and markers of success and bureaucratic infrastructures such as background checks and memoranda of understanding (MOUs) serve as agents of bureaucratic 
violence within ADR practice. Building upon anthropological theorisation of documents as part of dynamic sociocultural worlds and the bureaucratisation of and bureaucratic violence perpetuated by non-profit organisations, this article uses multi-sited ethnographic research in the United States to illustrate the complex lives of documents in community mediation and restorative justice (RJ) practice.

This article uses ethnographic research to illustrate how documents and their circulation within bureaucratic infrastructures are used as tools of social control in ADR contexts, thus contributing to growing literature on the social life of documents (Bernstein and Mertz 2011; Eldridge 2018; Eldridge and Reinke 2018; Ellison 2017; Gupta 2012; Nakueira 2019; Reinke 2018). Documents are often idealised by ADR practitioners as necessary for standardising procedure and process while they may simultaneously extol the virtues and values of flexibility inherent in ADR mechanisms. For example, during a meeting of ADR practitioners in northern California, attendees simultaneously reasserted mediation as an 'innate' skill that allows for flexible, needsbased, participatory justice, and which all humans are capable of and, in fact, have a natural knowledge and inclination to use. However, they simultaneously called for increased standardisation of the field and professional certification requirements - all of which require greater documentation and bureaucratic machinery and would potentially undercut the participatory, flexible and needs-based approach of mediation.

ADR mechanisms exist within a spectrum of relation to the state and its formal laws. In some cases, ADR is codified, such as the mandated use of mediation for divorce in much of the United States. In other contexts, ADR is only tentatively regulated by the state. This article grapples with community mediation and RJ in the United States as two forms of ADR. For practitioners of these two frameworks, their justice process is simultaneously shaped and protected by the state via laws (i.e. confidentiality protection), and outside state control (i.e. limited regulations and guidelines for practice). And although many of these organisations initially began with community-based missions to locate justice locally and draw upon a given community's 'people power' as a way to subvert state control and violence, these organisations and their practitioners have increasingly aligned themselves (voluntarily) or are subsumed by (involuntarily) the state (see Reinke 2018). This mirrors the mimetic representations and performances we see in the non-governmental organisational and non-profit worlds more generally (see Bernal and Grewal 2014; Fisher 1997; Lewis and Schuller 2017). ADR organisations, both where they exist as ostensibly community-driven 
or as codified arms of state law, sound and seem very much like the state insofar as modes of discourse and performative processes pervade everyday life in the ADR office (on mimetic representation of the state, see Das 2006). Documents and the bureaucratic infrastructures that give them life through their creation, circulation and death are instrumental in shaping the relationships between the state and ADR organisations, the organisations and their clients.

I consider that by using ethnographic inquiry to locate documents at the intersection between state and organisation, organisation and client, we make visible the bureaucratic violence inherent in ADR. Documents play an essential role in negotiations of power between ADR organisations, the state and clients. Organisations marshal case files, confidentiality agreements, MOUs and background checks to standardise and professionalise both their practice and their relationship to the state in an attempt to displace the monopoly of justice from the state into the hands of citizens. Conversely, state laws governing the use of ADR, confidentiality limitations and guarantees and grant-making processes reassert the primacy of state law in the dynamic context of justice practice. I discuss the use of documents as instruments of bureaucratic violence in $\mathrm{ADR}$, as well as the qualities of specific particular types of documents (MOUs, background checks, case files), and then the absence of documentation to demonstrate these issues. Although anthropologists may have historically rarely given documents their due in methodological and analytic inquiry because of traditional research contexts or interests (see Hull 2012: 12), Laura Nader's (1969) call to 'study up' and the subsequent shift towards examining industrialised and bureaucratised societies have given rise to scholarly works that locate written documents at the centre of social life. Documents generated by bureaucracies include record keeping, memos, reports, files, MOU and other paper and electronic artefacts that document our social world. These material artefacts exist as an account of the organisation's sociocultural life, the analysis of which can serve as the basis for anthropological inquiry.

For many cultural anthropologists, the study of documents is not sexy. Documents have been presented by Bruno Latour as 'the most despised of all ethnographic subjects' (1988: 54) and are often considered things that are 'simply standing between the things that really matter' (Hull 2012: 12). Historically, for some ethnographers, documents were seen as clutter that obscures the social reality, rather than providing an authentic mechanism for thoughtful, engaged and sustained ethnographic inquiry. Increasingly, an anthropological focus on documents 
demonstrates the spaces for archival and textual methodologies. The material in this article adds to literature illustrating how documents offer specific insights on our interactions with justice infrastructures.

Writing remains the primary technological tool for coordinating and controlling bureaucratic practice in justice contexts. While some scholars investigating institutions and legal anthropological topics have examined writing itself (Borrelli and Lindberg 2019; Ellison 2017; Gupta 2012; Sheehan 2018), many overlook writing as a necessary and invaluable part of bureaucratic processes and, thus, the ways in which writing shapes daily routine, processes and programmatic outcomes (Hull 2012).

The article builds on the work by political and legal anthropologists have, in recent years, begun to systematically examine documents as a focus of inquiry, rather than a side-lined component, and to consider the political lives and implications of these documents (Barrera 2018; Borrelli and Andreeta 2019; Borrelli and Lindberg 2019; Chelcea 2016; Ellison 2017; Harper 1997; Höhn 2013; Riles 2006; Sheehan 2018; Suerbaum 2018; Trundle and Kaplonski 2011).

\section{Positionality in ADR research}

The San Francisco Bay Area has been a place of alternative justice innovation and advocates seeking to address social issues (see Reinke 2019). It is home to the nation's longest running community mediation centre, San Francisco Community Boards and numerous other RJ and community mediation non-profits. Ethnographic data was collected in the San Francisco Bay Area (2014-2015) and northern Virginia (2016-2017) among paid ADR staff and unpaid volunteers and their clients.

From 2014-2015 I conducted ethnographic research throughout the Bay Area, working as a volunteer intern and case developer, where I observed mediations and casework, participated in and observed trainings for new practitioners, interviewed paid and volunteer ADR practitioners within organisations and those that operated as solo practitioners or entrepreneurs, and examined their archival records (case files). In these capacities, I observed and assisted with approximately two hundred cases. It was immediately clear that bureaucracy was a key part of organisational life. Walls of the office were lined with paper files. Paper files and digital files were required to have complementary, but different, documents tracking each case through creation, development and conclusion. The existence of these documents - and my 
concomitant responsibility for curating them - turned my analytical focus to the role of paper in mediating the substance of ADR cases and definitions of success, as well as the presence and absence of documents in paper or digital footprints.

Whereas the Bay Area has a long history of alternative justice and ADR engagement, Virginia is a relative newcomer to community mediation and RJ and RJ was codified into law only 11 years ago, providing an opportunity to analyse relatively new ADR non-profits. From 2016 to 2017, I interviewed paid and volunteer RJ practitioners working across various contexts, including within school settings, prisoners nearing parole and life-sentence inmates, and observed non-profit ADR staff meetings in northern Virginia.

While I had more intimacy of observation with case files in the Bay Area, I developed greater understanding and familiarity with the larger bureaucratic machinery - such as MOUs and background checks - to operate ADR work in Virginia where these were being actively negotiated between non-profits and state and county governments. Despite differences in the location of these two research sites, in both contexts practitioners and organisation leaders debated the utility of close relationships with the state and the bureaucratic machinery required to make those relationships possible. In northern Virginia, the need for documentation to gain access to clients was the key narrative of bureaucracy and bureaucratic violence, while in the Bay Area, documentation was perceived as necessary to evidence programmatic success for economic support - a continuous and underlying theme utilised to promote bureaucratisation.

\section{Documents as bureaucratic tools}

The management of the modern office is based upon written documents (the 'files'), which are preserved in their original or draught form. There is, therefore, a staff of subaltern officials and scribes of all sorts. The body of officials actively engaged in a 'public' office, along with the respective apparatus of material implements and the files, makes up a bureau. (Weber 1978: 957)

Following Max Weber, writing materialises knowledge and establishes relationships between discourse and people, actions, objects and processes. Documents, together with the officials responsible for producing and curating them, embody the office setting Weber describes in the preceding quote. The resulting technocracy is what he terms 'technical 
superiority' over other organisational systems, in which bureaucracy marshals speed, clarity of procedure and knowledge, and practical precision such that it is the optimal organising apparatus. But although Weber recognised that it is the combination of documents and individuals that constitute the space and operations of a bureaucratic office, he failed to examine documents as active agents within this dynamic sociocultural world.

Scholars often imagine documents and their circulation as key mechanisms within bureaucratic institutions that inscribe and codify meaning, are shaped and reshaped by the individuals who produce and curate the documents and make and remake how citizens relate to the state and vice versa. Following Latour (2005), documents can be considered mediators that 'transform, translate, distort and modify the meaning ... they are supposed to carry' (39). As the spoken word may be a mediator of meaning between discursive participants, so too is writing. Writing is both a process and a tool for inscribing meaning and significance. The importance of the process of writing and the resulting documents is quite evident when we consider the myriad contexts in which writing has been championed or applauded, but also burned, banned or surveilled as a mechanism of social control.

Material culture, such as uniforms or office buildings, is central to the reproduction of the state and its legitimacy (Borrelli and Lindberg 2019; Cabatingan 2018; Das 2006; Das and Poole 2004; Hansen and Stepputat 2001; Hull 2012; Messick 1993; Sharma and Gupta 2006), and writing is no different. Bureaucratisation through documents and infrastructures removes the state from the citizenry (Scott 1988). When researchers consider texts as part of state bureaucratic infrastructures, it is evident that writing is an effort at real, perceived or imagined force and domination: it can define access to resources and even life itself (at least in the eyes of the state) (see e.g. Chavez 2012; De Genova 2005).

Anthropologists have examined the role of bureaucratic organisation and documents in creating and perpetuating violence among citizens. For example, David Graeber states that 'institutions involved in the allocation of resources within a system of ... rights regulated and guaranteed by governments in a system that ultimately rests of the threat of force' (2012: 112). Others (Auyero 2012; Borrelli and Lindberg 2019; Eldridge 2018; Gupta 2012; Guyol-Meinrath Echeverry 2018; Kim 2018; Nakueira 2019; Reinke 2018; Sheehan 2018; Zenker 2015) have marshalled ethnographic data and insights to reveal how bureaucratic infrastructures, their associated rules (both written and unwritten) and insider knowledge work to cultivate structural violence 
that disproportionately harms particular sociocultural groups. The violence of bureaucracy has also been imagined as everyday - manifest in regulations and lack thereof, rituals, routines and the availability of resources (Borrelli and Lindberg 2019; Rajan 2001).

At their core, bureaucratic institutions that perpetrate violence rely upon documents to implement that violence. Documents exist both to mediate this violence, but also to obscure it within technical language that is only accessible to the educated. In ADR, requisite certifications for practice and cumbersome documentation processes often make this work inaccessible to the general public, creating an elite class of conflict resolvers that mirrors the state and formal law to which they were originally supposed to be an alternative. The central role of documents as a mediator of interactions between bureaucratic spaces and bureaucrats and the general public then allows the state to implement mechanisms of social control. The repetitive bureaucratic practices that shape documentation and writing for, of, and about the state are central to how its citizens define, imagine and encounter that state (Gupta 2012; Heyman 1995).

While writing is a repetitive process that shapes how we think about and interact with the state, there is also an aesthetic significance of documents. Documents and writing exist beyond knowledge production; instead, the patterning of language (see Riles 20088) and how those patterns are placed within a regime of authority (Hull 2012) also work to dynamically shape their effects within the sociocultural world in which they circulate. The power of documents is thus not only in their very existence, but in their aesthetics. Within alternative justice, the terminology, phrasing and placement of these documents all have the potential of being scrutinised by formal law and its lawyers. A misworded sentence in a confidentiality agreement may render it useless; an MOU missing the correct signature is obsolete.

However important, documents do more than inscribe meaning upon paper or in the digital world. It is also the circulation of those documents among a group (a community) of users that helps us situate writing within bureaucratic institutions and as part of the administration of social control. Writing is created by and circulates within communities, shaping and being shaped by its dynamic interactions within these spaces and places (see Bernstein and Mertz 2011).

When a client initially calls an ADR organisation, a written record of that event is produced. This record may lead to a case file document that circulates in the digital and physical worlds between interns and case developers, who each add information and documentation as it 
arrives. But other documents, such as confidentiality agreements, are kept only in the physical form and circulate between the ADR practitioners and parties in the conflict resolution space; this document is then placed in its appropriate physical file, then in the correct filing cabinet. Thus, ADR is a generative space for researching the role of documents in social justice efforts to mitigate state violence. Practitioners striving to mitigate the criminalisation of youth, mass incarceration of marginalised groups, and build peace in tumultuous communities leverage documents in both their presence and their absence. Documents, such as memoranda of understanding between organisations and the state, background checks and identifications requirements, along with filing systems meant to contain and organise them often become impediments to achieving these social justice goals.

\section{The absence and presence of paperwork}

Following James Scott, the process of bureaucratisation may remove the state and its practitioners 'at least one step - and often several steps ... from the society' (1998: 76). The displacement of the state from the citizens it is meant to serve is also replicated in the history of alternative justice. Alternative justice became popularised in the United States beginning in the 1970s as the failures of the legal system, such as violent policing and its disproportionate and deleterious effects on marginalised groups, became more evident to publics not normatively affected by this violence. In order to reach social justice goals and to mitigate the legal system's monopoly on justice, non-profits offering alternative justice marshal paperwork, such as MOUs with the state. However, the absence of paperwork that tracks and traces human actions and activities may also mitigate the criminalisation of behaviour.

At the individual state level, documentation codifies alternative justice within the US context. Such mechanisms are included in state penal codes, standardising when they can be used as legitimate means for conflict resolution that will be recognised by the state. Virginia, for example, has codified RJ, a conflict resolution mechanism that is widely used in the United States, creating legal documents and potential precedents for RJ implementation throughout the state and elsewhere in the country. The Virginia legal code specifies RJ for use during communitybased probation for non-violent offenders (\$9.1-174); as part of a suspended sentence (\$19.2-303); for juveniles (when not tried as an adult) (§16.1-278); as part of victim impact statements (§19.2-299.1; §16.1-273); 
and for victim-offender reconciliation programs (\$19.2-11.4) (see SJR 362). Judges, lawyers and police officers are primarily responsible for bridging cases between the formal and informal legal realms by diverting appropriate cases to non-profits offering acceptable or 'legitimate' justice services. Thus, the necessity for memoranda of understanding between non-profits and the state becomes clear as a practical tool for negotiating and navigating this diversionary process.

Paperwork, or, rather, the absence of paperwork and a paper trail that could criminalise individuals, is one way in which practitioners leverage bureaucratic infrastructures to undermine state violence. For example, it is now commonplace to have a school resource officer (SRO) within the school setting; the SRO is a sworn law enforcement officer placed within the school to respond to disputes. Calls to place officers within US schools have been increasing as high-profile school violence cases such as the Sandy Hook Elementary School massacre have garnered national attention. Using SROs has thus become normative as social control via surveillance and disciplining behaviour has been systematically transferred from the teachers and the classroom to the state and courtroom (Hirschfield 2008, 2011; Theriot and Cuellar 2016). Most SROs are not trained in alternative justice and rely solely on their police training to guide their actions. Laura, ${ }^{1}$ a conflict mediation practitioner with her own children in the school system where she volunteers, wondered whether SROs could be trained in alternative justice, 'because that's your first line of folks if they come on the scene ... If they're called in, instead of them carting off the child and having to fill out paperwork or whatever on them, you know just see if they can implement some of the [practices] right then and there'. The remainder of this section uses two separate examples from two interview participants, Laura and Susan. These practitioners illustrate the role of paperwork in its absence and its presence in subverting state violence or in gaining legitimacy from the state itself.

In Laura's context, the absence of paperwork that evidences a child's misbehaviour keeps them from having a criminal record that may trigger zero tolerance policies. Once a child has been detained by an SRO, they are in conflict with the legal system, and zero-tolerance policies may be enacted, placing the child at risk for criminalisation and even incarceration (see Theriot and Cuellar 2016). The northern Virginia city in which Laura works has a nearly 25 per cent poverty rate, significantly higher than the national average (USCB 2019), and some of the state's lowest graduation rates (Teran-Tapia 2019; VDOE 2020). Virginia has been leading the country in their referral of youth to law enforcement 
and use of SROs in public schools. This is coupled with the disproportionate referrals of Black students and those with disabilities to law enforcement (Langberg and Ciolfi 2016). The social justice issues of disproportionate policing and treatment coupled with limited school resources and limited student resources to support their growth and development pose significant challenges for youth.

Laura's suggestion to train SROs in alternative justice practices is part of a broader call to implement ADR training for administrators, teachers and staff support in K-12 schools. Laura continues: 'It becomes a part of the culture of the school. Everybody's got to be on the same page, because if the teachers and the SRO people and the principal aren't on the same page, no matter how many [RJ] classes and trainers you do for the kids, it's not going to make any difference'. From this practitioner's perspective, implementing alternative conflict resolution philosophies and training students, teachers, SROs and administrators in these principles will eventually mean 'they take ownership of it' in a sustainable way. Laura does not claim that extracting SROs from the school environment is the proper way to address the school-to-prison pipeline; rather, she advocates for the widespread training of all adults who work with children, as well as training the children themselves. In this way, Laura wants to use the existing system to advocate for the adoption of RJ in schools, which will decrease the likelihood that criminalising paperwork in zero-tolerance policy environments will be generated. Non-profits do not have the capacity to continually offer these services in the school setting and must consistently apply for and receive grants and political and social support for their work in order to continue operating within this context. Paperwork, or the lack thereof, in Laura's ADR context serves to subvert state power. Training SROs in non-criminalising intervention techniques such as RJ would reduce the likelihood that marginalised youth are processed through the legal system, becoming a statistic in the school-to-prison pipeline.

However, just as the absence of paperwork can be used to mitigate state power and structural violence, documents can also be used to reify that power. Non-profits offer alternative justice in the US marshal paperwork as a mechanism to subvert state control but also to legitimise their work in the eyes of the state. In this sense, the process and significance of writing and its subsequent interpretation is inseparable from the contexts and conditions that produce it (see Chartier 1994). When researchers examine the context of alternative justice, the documents themselves 'bear the double sign of the state's distance and its penetration into the life of the everyday' (Das and Poole 2004: 25). Some documents such as 
memoranda of understanding and confidentiality agreements are necessary for informal conflict resolution processes to be deemed legitimate in the eyes of the state, a necessity that alternative justice practitioners support. ADR practitioner interviewees repeatedly said that legitimacy in the eyes of the state is of supreme importance, especially for those practitioners working within the confines of the legal system. Practitioners working within the juridical grey space where informal and formal law meet are concerned about countering a stereotype that they are too 'warm and fuzzy'. They want others working in this space, such as judges and lawyers, to respect their work and recognise them and their practices as legitimate forms of conflict resolution.

I turn to the second example, Susan, a Virginia RJ practitioner and retired lawyer working within the court system. She points out: 'One of our shortfalls is that we tend to be too warm and fuzzy and not business oriented'. She elaborated: 'We're not going to be deemed legitimate if we're homemakers and retired chaplains coming for free'. Susan believes that being volunteers, even well-trained volunteers who have undergone the legally required number of training hours for conflict resolution, supports the stereotype that they are too 'warm and fuzzy.' She counters this stereotype by arguing for paperwork and fees for the services they provide, which will in turn support the non-profit's work. Susan emphasises the need for written rules and guidelines, such as MOUs, that codify their organisation's work in relation to the state but also ensure their centrality to state justice procedures. Legitimacy in this context is achieved through regulations, rules and the standardisation of alternative justice practices. Everyday processes and procedures occur via filing mechanisms, managing relationships with state entities via textual materials (e.g. MOUs) and quantifying programmatic achievements. Following Akhil Gupta, practitioners place increasing 'emphasis on rules rather than on achieving results', which 'has the effect of preserving bureaucratic order, regardless of its consequences for the clients of those programs' (2012: 50).

\section{Access through background checks and state identification}

Documents, in both their presence and their absence, play a significant role in mediating the daily interactions and activities of alternative justice practitioners and state actors as they negotiate and struggle over power, authority and ownership of justice within this informal-formal justice nexus. Documents and the bureaucratic infrastructures that are 
created to appropriately place and process them impact the daily lives of practitioners attempting to implement programs. I consider here the bureaucratic infrastructure created to mediate a face-to-face interaction between a justice practitioner and their client. Alternative justice practitioners working with/in the formal legal system must navigate infrastructures defined by state documents to undergo the required background checks in order to receive an ID card. Practitioners must be able to produce this ID card before a face-to-face introduction, consultation or conflict resolution process with their clients. Social associations are therefore mediated by ID cards, themselves the product of extensive paperwork and biometric data collection such as fingerprinting.

Camila, a Virginia practitioner, shares her experiences replacing an ID card after their organisation's MOU was struck down by the state, and then reinstates:

[I was] ripping and running about town just ... to actually find my badge. And then I went to the city and the Court Services Units and now we have to redo it for the county ... I mean you have a snippet [of volunteers] who are retirees, but a lot of us have full-time jobs ... My loyalty is with the cause, but it's like I always told you, I have bills to pay ... I'm always going to volunteer, I just can't be doing all of that now.

The ID provides alternative justice volunteers like Camila with legal access to ordinarily inaccessible people, such as individuals detained by police, and places, such as correctional institutions. Legal access is managed by the state, which monopolises authority and access by defining identity and constructing the bureaucratic infrastructures that moderate who has access to peoples and places, as well as when and how they receive that access (see Torpey 2000). To gain legal access, volunteers must fill out paperwork and undergo a background check, but they must often do this at multiple locations (e.g. county clearance, state clearance). Their same legal and biometric information, including name, address, contact information, arrest and detention histories and fingerprints, are replicated at various times and places. The practitioner must often pay fees to have their information processed. Thus, the very process of doing the paperwork is contingent upon a consistent and well-maintained relationship with the state, and it is a taxing process for practitioners like Camila. Volunteers become mired within the bureaucratic infrastructures that are created by the state and the nonprofit in the quest for legitimacy.

In this sense, while the written word upon the document might be static, the documents themselves are dynamic (see Harper 1997). 
Documents circulate (often violently) within these communities and are shaped by their interactions between these volunteer practitioners and the state, for which they must produce this paperwork. A single change to their MOU with the state and these documents must all be reproduced to the satisfaction of that state. Thus, the social life of background checks is a tumultuous one. However, the background check is only one small piece in the totality of bureaucratic documents required to create and manage an alternative justice non-profit.

\section{Formalising relationships through memoranda of understanding}

Documents thus become essential in the quest for legitimacy from the state. Documents are leveraged by alternative justice practitioners as a mechanism by which to counter the stereotype that alternative justice is 'warm and fuzzy.' This further allows them to gain tangible benefits from the state, such as case referrals and funding. The relationship between the state and these organisations may be solidified through MOUs.

The MOU is a document that may be binding between two or more entities but does not have the force of law. It binds entities together and enumerates their roles and responsibilities to one another. Alternative justice non-profits develop MOUs with state entities, such as the Department of Juvenile Justice or a correctional facility, that outline when and how they may become involved in legal cases. Contained within the MOU is a stated purpose of the document, a statement of mutual interests or benefits for the parties included in the MOU and the rights and obligations of all parties to the MOU. For example, an MOU between a state facility and ADR non-profit might specify that the non-profit agrees to ensure volunteers or paid facilitators have undergone background checks and have appropriate ID cards identifying them before they can gain entrance to the facility. Simultaneously, the facility would agree to allow access into the facility and to individuals in custody provided the non-profit adheres to the guidelines.

Without an MOU, the organisation does not have access to individuals who have been detained by the legal system. The MOU includes the parties in a given relationship, the purpose of the understanding, the authority upon which the MOU is developed, relevant background information, objectives of the understanding, the responsibilities of all parties involved and who is responsible for oversight. It is a document that binds together alternative justice organisations to the entities that 
will facilitate their service provision, such as correctional facilities, schools and other state departments. Thus, the MOU operates as the bureaucratic gatekeeper to an alternative justice organisations client.

Paperwork is also used to make non-profits operate more like a business, because, according to one practitioner, 'at the end of the day, this is a business' and you have to 'put that stuff on paper'. Becoming more like a business via MOUs and written guidelines and regulations is considered part of the process of gaining legitimacy from the state. However, the quest to become more businesslike is also an attempt to achieve legitimacy in the eyes of actual and potential donors. Susan was also a long-time fundraiser for various capital campaigns, and reflects on this need: 'I'm not afraid to ask anybody for money. But I can't ask for money for some warm and fuzzy thing... I need more than anecdotal evidence'. Legitimacy stems from quantitative data, written rules and guidelines and a definitive relationship with the state. Following Sally Engle Merry (2016), quantifying the care provided by alternative justice services inevitably strips it of its core principles such as empathy. The need to become more like a business is linked to a need to oversimplify programmatic outcomes for these outcomes to be more easily digestible to the potential donor and comparable to state outcomes. The need to become more like a business is, at its core, a need to become more like the state.

\section{Files as mediators of success}

Files are created for each case, and a single file encompasses the entire life cycle of that case, from first opening to its conclusion. Alternative justice non-profit walls are typically lined with filing cabinets holding within them the histories, challenges and successes of conflicts over their years of operation. While documents are used as a tool of social control (see Crozier 1967; Goody 1986; Torpey 2000; Yates 1989), files and filing systems in this context have another (intended or unintended) outcome of making, shaping or transforming institutional memory of events. For anthropologists working with and within non-profits and NGOs, documents serve as the organisation's evidence of success. According to Sabrina Höhn (2013), 'to document' success and social action is a primary responsibility of individuals working within NGOs. A failure to document repeated successes places funding and political and social support in jeopardy. However, documents are more than objects that objectively prove success or failure; they are actively 
shaped in various ways by individuals seeking to achieve (or appear to have achieved) particular goals sought by that organisation, the state, funders or other stakeholders.

Among practitioners, 'success' in alternative justice is generally documented quantitatively through recidivism rates (if it is a criminal offense) and user satisfaction, generally a survey at the conclusion of justice proceedings (see Dignan 1992; Smith 2011). These markers of success matter and are presented to donors, grant agencies, government agencies and policymakers as evidence of the utility and effectiveness of alternative justice program. However, the practitioners themselves determine which cases have been successful. At the conclusion of cases, they will mark a case unresolved (or a similar term, such as inconclusive) or as a 'success.' The parameters for this distinction are often quite blurry. Some practitioners consider it a success if the parties agreed to continue their discussions, debates and deliberations, while others believe it is a success only if the parties wrote out a resolution agreement with specific terms, responsibilities and timelines for action. The files themselves thus become a somewhat disorganised web that must be disentangled to determine exactly what 'success' means to the practitioners and how this is operationalised in their daily work.

I consider some of the complexities in the following example. In 2015, I assisted the development of a complex case that involved multiple co-workers at another non-profit in the Bay Area who were having difficulty communicating effectively and agreeing upon the broader goals and mission of their organisation, which was also facing significant political and economic challenges. After documenting our multiple phone calls and setting up their community mediation session, I perused the files to see the outcome of their case. The physical file has a checkmark next to 'resolved' but included no agreement or conclusion. The digital file record similarly indicated this case was successfully resolved but further noted that no agreement was reached. As this case illustrates, a case may be marked 'successful' in both the digital and paper files. However, upon perusing the depths of the paper trail within that file, it becomes apparent that there was no resolution and no signed agreement. It was possible that the case was unsuccessfully concluded beyond a verbal commitment to continuing conversations and collaborations between the parties in resolving the conflict. The files themselves raise unanswered questions about designations of success in a nexus whereby alternative justice practitioners are constantly negotiating legitimacy from the state. Files thus exist in part to shape collective understandings of what constitutes 'good' justice practices. 
Documents, in this sense, are tools for managing the memory of a particular case and definitions of 'good' justice practices. Writing operates as a mechanism for deflecting criticism and intensifies what Ernst Herzfeld terms the 'fetishization of language' (1992: 118). Writing and the static nature of the file, as opposed to the dynamic, face-to-face interactions or process of managing identities or MOUs, defines the outcome of an alternative justice case and thus the memory of cases and relationships with the state and other entities. The justice file itself is often split between physical paper and digital formats. A physical file exists to provide rudimentary checklists and dates of when the case moved from one stage to another, such as from initial opening to initial follow-up to its closing. It includes letters sent to the parties in question, signed confidentiality agreements, final resolution and perhaps survey feedback on the conflict resolution process. The digital file, on the other hand, documents each individual interaction the practitioners have with each member of the conflict. While it does not typically contain confidentiality agreements or many of the other pieces of paperwork found in the physical file, it does provide an extensive overview of the dynamic conversations and interactivities between non-profit and parties.

In each of these formats, there is an absence and presence of particular information (documentation). The physical file does not contain each individual interaction a practitioner has with a client and includes minimal information about the outcome of a case, as evidenced by the non-profit community mediation example. Nor does the digital file contain confidentiality agreements, survey feedback or the substance of final agreements and resolutions. The physical file is often a relatively thin folder in contrast to what we normatively expect from legal proceedings. The lack of documentation often means there is little evidence attesting to how a case was determined to be 'successful' or 'unsuccessful'; the reader or analyst is left to wonder what was left out of the files under the guise of confidentiality, lack of time or ease of storage and access.

\section{Conclusion}

Legal writing codifies alternative justice: when and where it can be used and for whom. Paper files in the examples demonstrated an extent of tangible evidence attesting to the ongoing work of the justice organisation, leaving it to digital writing to inscribe further meaning. This is 
also where confidentiality forms add another written layer to a process that is already defined and inscribed by the written word. Documents are created and circulate within this contested middle space between formal law and informal justice processes: the informal-formal justice nexus. Within this space, files, background checks and memoranda of understanding exist as documentation of a person's conflict and their resolution process. For some practitioners, it is clear that their work is intrinsically linked into this process of writing rules, understandings and filings. The state's demand for bureaucratic infrastructure has pervaded the practitioners own imaginings and perception of their work: paperwork and documentation are required for legitimacy. Thus, practitioners themselves demand that the hallmarks of business, including written guidelines, policies and procedures, are created and upheld by their non-profit.

Using Laura's experience with SROs in northern Virginia, I have argued that the absence of documents is a potentially effective tool for mitigating state violence, specifically the school-to-prison pipeline. Susan's concerns about legitimacy highlights the need for documents and bureaucratic processes and procedures such as MOUs. In this example, paperwork and abstruse bureaucratic infrastructures are considered a requirement in order to be taken seriously by the state with whom an alliance is perceived as integral. Files in both their physical and digital forms illustrate further the need to document success and social action within non-profit contexts as a form of legitimacy. Similarly, the necessity of state identification and background checks manifest as time-consuming and technocratic routines and rituals for ADR volunteers such as Camila who are seeking to promote social justice.

The push to displace justice-seeking processes from the state and into the hands of communities and community members that began in the 1970s in the United States has become mired in the requisite paperwork and procedures deemed necessary to make the work 'legitimate' in the eyes of the state. Ethnographic inquiry that looks at documents instead of just through them includes an examination of documents the files, memoranda of understanding, confidentiality agreements and background checks - that illuminate these dynamics. The documents propel the daily workings of alternative justice and reveals how the creation, curation and circulation of these documents affects a nonprofit's daily work, which in turn affects their ability to undermine state violence such as mass incarceration and the school-to-prison pipeline. By controlling documents and the ways in which they define and document success, alternative justice non-profits leverage bureaucracy to re- 
shape relations with the state and the substance and meaning of justice in the process. This ethnographic focus inclusive of examining a range of documents that propel the daily working of alternative justice reveals how the creation, curation and circulation of these documents affects the non-profit's daily work, reshapes relations with the state and has repercussions for the substance and meaning of justice for individuals in conflict.

\section{Acknowledgements}

Research for this article was generously funded by the Georgia College \& State University Paul D. Coverdell Endowed Chair Fellowship and by the University of Tennessee Yates Dissertation Fellowship and Thomas Family Fellowship.

Amanda J. Reinke is Assistant Professor of Conflict Management in the School of Conflict Management, Peacebuilding and Development at Kennesaw State University. She uses structural, bureaucratic and everyday violence to analyse disaster recovery and conflict management efforts in the United States.

ORCID iD: 0000-0001-9184-2032 | Email: areinke@kennesaw.edu

\section{Note}

1. All names are pseudonyms.

\section{References}

Auyero, J. (2012), Patients of the State: The Politics of Waiting in Argentina (Duke, NC: Duke University Press).

Barrera, L. (2018), 'Gatekeeping: Documents, legal knowledge, and judicial authority in contemporary Argentina', PoLAR 41, no. 1: 90-107, https://doi.org/10.1111/ plar.12242.

Bear, L. and N. Mathur (2015), 'Introduction: Remaking the Public Good: A new anthropology of bureaucracy', Cambridge Journal of Anthropology 33, no. 1: 18-34, https://doi.org/10.3167/ca.2015.330103.

Bernal, V. and I. Grewal (eds) (2014), Theorizing NGOs: States, Feminisms, and Neoliberalism (Durham, NC: Duke University Press).

Bernstein, A. and E. Mertz (2011), 'Bureaucracy: Ethnography of the state in everyday life', PoLAR 34, no. 1: 6-10, https://doi.org/10.1111/j.1555-2934.2011.01135.x. 
Borrelli, L. M. and S. Andreetta (2019), 'Introduction: Governing migration through paperwork', Journal of Legal Anthropology 3, no. 2: 1-9, https://doi.org/10.3167/ jla.2019.030201.

Borrelli, L. M. and A. Lindberg (2019), 'Paperwork performances: Legitimating state violence in the Swedish deportation regime', Journal of Legal Anthropology 3, no. 2: 50-69, https://doi.org/10.3167/jla.2019.030204.

Brown, S., C. Cervenak and D. Fairman (1997), Alternative Dispute Resolution Practitioners Guide (Washington, DC: US Agency for International Development).

Cabatingan, L. (2018), 'Fashioning the legal subject: Popular justice and courtroom attire in the Caribbean', PoLAR 41, no. S1: 69-84, https://doi.org/10.1111/ plar.12254.

Chavez, L. (2012), Shadowed Lives: Undocumented Immigrants in American Society (Belmont, CA: Wadsworth).

Chartier, R. (1994), The Order of Books: Readers, Authors and Libraries in Europe between the Fourteenth and Eighteenth Centuries, trans. L. G. Cochrane (Cambridge: Polity).

Chelcea, L. (2016), 'Kinship of paper: Genealogical charts as bureaucratic documents', PoLAR 39, no. 2: 294-311, https://doi.org/10.1111/plar.12195.

Crozier, M. (1967), 'Sociologie des organisations et institutions internationales', Information (International Social Science Council 6, no. 4: 53-62, https://doi.org/ 10.1177/053901846700600403.

Das, V. (2006), Life and Words: Violence and the Descent into the Ordinary (Berkeley, CA: University of California Press).

Das, V. and D. Poole (2004), 'State and its margins: Comparative ethnographies', in V. Das and D. Poole (eds), Anthropology in the Margins of the State: Comparative Ethnographies (Santa Fe, NM: School of American Research Press), 3-34.

De Genova, N. (2005), Working the Boundaries: Race, Space, and 'Illegality' in Mexican Chicago (Durham, NC: Duke University Press).

Dignan, J. (1992), 'Repairing the damage: Can reparation work in the service of diversion?' British Journal of Criminology 32, no. 4: 453-472.

Eldridge, E. R. (2018), 'Administrating violence through coal ash policies and practices', Conflict and Society 4, no. 1: 99-115, https://doi.org/10.3167/ arcs.2018.040109.

Eldridge, E. R. and A. J. Reinke. (2018), 'Introduction: Ethnographic engagement with bureaucratic violence', Conflict and Society 4, no. 1: 94-98, https://doi.org/ 10.3167/arcs.2018.040108.

Ellison, S. H. (2017), “'You have to comply with paper": Debt, documents, and legal consciousness in Bolivia', Journal of the Royal Anthropological Institute 23, no. 3: 523-542, https://doi.org/10.1111/1467-9655.12651.

Fisher, W. F. (1997), 'Doing good? The politics and antipolitics of NGO practices', Annual Review of Anthropology 26: 439-464.

Goody, J. (1986), The Logic of Writing and the Organization of Society (Cambridge: Cambridge University Press).

Graeber, D. (2012), 'Dead zones of the imagination: On violence, bureaucracy, and interpretive labor', HAU: Journal of Ethnographic Theory 2, no. 2: 105-28, https:// doi.org/10.14318/hau2.2.007.

Gupta, A. (2012), Red Tape: Bureaucracy, Structural Violence, and Poverty in India (Durham, NC: Duke University Press). 
Guyol-Meinrath Echeverry, E. (2018), ‘Violence, development, and Canada's new transnational jurisprudence', Conflict and Society 4, no. 1: 167-185. https://doi.org/ 10.3167/arcs.2018.040113.

Hansen, T. B. and F. Stepputat (2001), States of Imagination: Ethnographic Explorations of the Postcolonial State (Durham, NC: Duke University Press).

Harper, R. (1997), Inside the IMF: An Ethnography of Documents, Technology, and Organizational Action (New York: Routledge).

Herzfeld, M. (1992), The Social Production of Indifference (Chicago, IL: University of Chicago Press).

Heyman, J. (1995), 'Putting power in the anthropology of bureaucracy: The Immigration and Naturalization Service at the Mexico-United States border', Current Anthropology 36, no. 2: 261-287.

Hirschfield, P. J. (2008), 'Preparing for prison? The criminalization of school discipline in the USA', Theoretical Criminology 12, no. 1: 79-101, https://doi.org/ $10.1177 / 1362480607085795$.

Hirschfield, P. J. (2011), 'School surveillance in America: Disparate and unequal', in T. Monahan and R. D. Torres (eds), Schools Under Surveillance: Cultures of Control in Public Education (New Brunswick, NJ: Rutgers University Press), 38-54.

Höhn, S. (2013), 'The object of activism: Documents and daily live in Namibian NGOs', PoLAR 36, no. 1: 99-117, https://doi.org/10.1111/plar.12005.

Hull, M. S. (2012), Government of Paper: The Materiality of Bureaucracy in Urban Pakistan (Berkeley: University of California Press).

Kim, J. (2018), 'Perspectives from the ground: colonial bureaucratic violence, identity, and transitional justice in Canada', Conflict and Society 4, no. 1: 116-134. https://doi.org/10.3167/arcs.2018.040110.

Langberg, J. and A. Ciolfi (2016), Protecting Childhood: A Blueprint for Developmentally Appropriate School Policing in Virginia (Charlottesville, VA: Legal Aid Justice Center).

Latour, B. (1988), Science in Action: How to Follow Scientists and Engineers through Society (Cambridge, MA: Harvard University Press).

Latour, B. (2005), Reassembling the Social: An Introduction to Actor-Network-Theory (New York: Oxford University Press).

Lewis, D. and M. Schuller (2017), 'Engagements with a productively unstable category: Anthropologists and nongovernmental organizations', Current Anthropology 58, no. 5: 634-651, https://doi.org/10.1086/693897.

Merry, S. E. (2016), The Seductions of Quantification: Measuring Human Rights, Gender Violence, and Sex Trafficking (Chicago: University of Chicago Press).

Messick, B. (1993), The Calligraphic State: Textual Domination and History in a Muslim Society (Berkeley, CA: University of California Press).

Nader, L. (1969), 'Up the anthropologist: Perspectives gained from "studying up'", in D. Hymes (ed.), Reinventing Anthropology (New York: Random House), 284-311.

Nakueira, S. (2019), 'Governing through paperwork', Journal of Legal Anthropology 3, no. 2: 10-28, https://doi.org/10.3167/jla.2019.030202.

Rajan, S. R. (2001), 'Toward a metaphysic of environmental violence: The case of the Bhopal gas disaster', in N. L. Peluso and M. Watts (eds), Violent Environments (Ithaca, NY: Cornell University Press), 380-398.

Reinke, A. J. (2016). 'Advancing social justice through alternative justice in the San Francisco Bay Area' (PhD diss., University of Tennessee). 
Reinke, A. J. (2018), 'The bureaucratic violence of alternative justice', Conflict and Society 4: 135-150, https://doi.org/10.3167/arcs.2018.040111.

Reinke, A. J. (2019), 'The (im)possibilities of social justice through alternative justice in the San Francisco Bay Area', Entanglements 2, no. 1: 111-125.

Riles, A. (ed.) (2006). Documents: Artifacts of Modern Knowledge (Ann Arbor: University of Michigan Press).

Scott, J. (1998), Seeing Like a State: How Certain Schemes to Improve the Human Condition Have Failed (New Haven, CT: Yale University Press).

Sharma, A. and A. Gupta (2006), 'Introduction: Rethinking theories of the state in an age of globalization', in The Anthropology of the State: A Reader, eds. A. Sharma and A. Gupta (Oxford, UK: Blackwell Publishing), pp. 1-42.

Sheehan, M. (2018), 'Migrant residents in search of residences: Locating structural violence at theinterstices of bureaucracies', Conflict and Society 4, no. 1: 151-166, https://doi.org/10.3167/arcs.2018.040112.

Smith, R. (2011), 'Developing restorative practice: Contemporary lessons from an English juvenile diversion project of the 1980s', Contemporary Justice Review 14, no. 4: 425-438, https://doi.org/10.1080/10282580.2011.616372.

Suerbaum, M. (2018). 'Become and "unbecoming" refugees: Making sense of masculinity and refugeness among Syrian refugee men in Egypt', Men and Masculinities 21, no. 3: 363-382, https://doi.org/10.1177/1097184X17748170.

Teran-Tapia, A. (2019), 'Richmond schools wrestle with low graduation rates', NBC 12, 6 May, https://www.nbc12.com/2019/05/06/richmond-schools-wrestle-with -low-graduation-rates.

Theriot, M. T. and M. J. Cuellar (2016), 'School resource officers and students' rights', Contemporary Justice Review, 19, no. 3: 363-379, https://doi.org/10.1080/10282580 .2016.1181978.

Torpey, J. (2000), The Invention of the Passport: Surveillance, Citizenship and the State (Cambridge: Cambridge University Press).

Trundle, C. and C. Kaplonski (2011) 'Tracing the political lives of archival documents,' History and Anthropology 22, no. 4: 407-414, https://doi.org/10.1080/ 02757206.2011.626777.

USCB (United States Census Bureau) (2019), 'QuickFacts: Richmond city, Virginia', https://www.census.gov/quickfacts/richmondcityvirginia.

VDOE (Virginia Department of Education) (2020), 'Virginia cohort reports,' accessed 13 June, http://doe.virginia.gov/statistics_reports/graduation_completion/ cohort_reports/index.shtml.

Weber, M. (1978), Economy and Society: An Outline of Interpretive Sociology (Berkeley: University of California Press).

Yates, J. (1989), Control Through Communication: The Rise of System in American Management (Baltimore, Maryland: Johns Hopkins University).

Zenker, O. (2015), 'De-judicialization, outsourced review and all-too-flexible bureaucracies in South African land restitution', Cambridge Journal of Anthropology 33, no. 1: 81-96, https://doi.org/10.3167/ca.2015.330107. 